\title{
Inflammatory Pseudotumor/Inflammatory Myofibroblastic Tumor of Spleen - A Case Report
}

\author{
Rubens Jovanovic ${ }^{1 *}$, Aleksandar Eftimov ${ }^{1}$, Svetozar Antovic ${ }^{2}$, Ognen Kostovski ${ }^{2}$, Bojan Labachevski ${ }^{3}$, \\ Aleksandar Nikodinovski ${ }^{3}$, Gordana Petrusevska ${ }^{1}$ \\ ${ }^{1}$ Institute of Pathology, Faculty of Medicine, Skopje, Republic of Macedonia; ${ }^{2}$ University Clinic of Digestive Surgery, Faculty \\ of Medicine, Skopje, Republic of Macedonia; ${ }^{3}$ Institute of Preclinical and Clinical Pharmacology with Toxicology, Faculty of \\ Medicine, Skopje, Republic of Macedonia
}

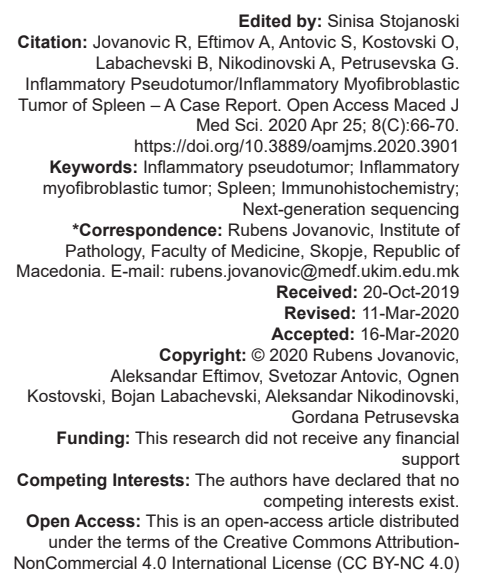

\section{Introduction}

Inflammatory pseudotumor (IPT) of the spleen is an extremely rare tumor-like lesion with approximately $<115$ published cases in adults until 2015, and probably not more than 116 cases until year 2017 , at the best of our knowledge [1], [2], [3], [4], [5], [6]. This entity was first introduced in 1984 by Cotelingam and Jaffe [1]. It is a lesion composed of proliferated spindle cells with admixed inflammatory cellular component of variable composition including lymphocytes, plasma cells, histiocytes, and granulocytes [1], [2], [3], [4], [5], [6]. Additional studies have demonstrated that spindle cells are in fact myofibroblasts, prompting the designation inflammatory myofibroblastic tumor (IMT) [2]. More recent studies have challenged the still controversial view that IPT and IMT are the same entity [7]. IPT is notorious for mimicking malignant neoplasm of the spleen, while its etiology and pathogenesis are not fully understood. IPT is more frequently found in other locations including orbit, digestive system, spinal meninges, soft tissues, bladder, liver, lymph nodes, and with lungs being a predilection site affected in age ranges from pediatric to elderly patients over 60, both males and females [6], [8], [9]. Although the pathogenesis is notfully understood, associations have been reported with bacterial and viral (Epstein-Barr virus [EBV], and human herpesvirus 8) infections, some immunological derangements, neoplastic processes, previous surgery, ventriculoperitoneal shunt, trauma, radiation therapy, and steroid usage [2], [3], [4], [5], [6], [7]. Contradicting views have been published about the relationship between EBV infection and occurrence of IPT, additionally linking the IPT to IMT, frequently used as a synonym according to some of the authors [4], [8], [10], [11], [12]. Besides publications that approximate IPT and IMT, or use the terms interchangeably [7], there are authors that oppose this view, stating that IPT of lymph nodes and spleen is biologically different from IMT [10], [11]. The main arguments for this distinction probably come from the findings that IMTs are more frequently associated with EBV infection, and approximately 50\% of them harbor anaplastic lymphoma kinase 1 (ALK1) rearrangements or activating mutations in one of three other receptor tyrosine kinases including ROS1, RET, and neurotrophic tyrosine receptor kinase 3 [7], [10], [11], [12]. Cases with aggressive behavior of IPT/IMT have been reported, either with local recurrences or even metastatic 
spread [2], [3], [4], [7], [8], [10], [11], [12], [13]. Although exceedingly rare, IMT may arise in the breast also [14], [15], posing a special differential diagnostic challenge, taking into consideration the broad range of other fibroblastic/ myofibroblastic breast proliferations such as fibromatosis, pseudoangiomatous stromal hyperplasia, nodular fasciitis, myofibroblastoma, and possibly phyllodes tumor with stromal overgrowth, which although rare in absolute numbers, comprise the majority of mesenchymal spindle cell lesions of the breast [16].

\section{Case Report}

A 61-year-old male was admitted at the University Clinic for Abdominal Surgery for splenectomy. One month before, he was incidentally diagnosed with splenic tumor during routine US examination for ill-defined abdominal discomfort. Computed tomography (CT) scan showed focal, $42 \mathrm{~mm}$ in diameter, hypodense lesion with peripheral postcontrast signal, which was interpreted as secondary neoplasm by the radiologist. However, primary splenic neoplasm was not excluded in the differential diagnosis. On admittance, the patient had no specific complaints and no symptoms or signs of interest, except for productive cough. CT scan of the thorax was negative, as well as gastric and colonic endoscopy. Laboratory findings were as follows: Conjugated bilirubin slightly elevated at $7.25 \mu \mathrm{mol} / \mathrm{L}$ (Ref. up to 6,8 ), globulins $25.1 \mathrm{~g} / \mathrm{L}$ (Ref. 27-35), and tumor markers (CA 72-4, CEA, CA 19-9, CA125) were negative; hemogram, coagulation status, enzymes (alanine transaminase, aspartate transaminase, alkaline phosphatase, and alpha-amylase), and C-reactive protein and metabolites (blood urea nitrogen, and creatinine) were within reference ranges. The patient's history contained nothing of interest for the present condition.

\section{Macroscopic presentation}

Removed spleen weighted $225 \mathrm{~g}$ and measured $119.5 \mathrm{~cm} \times 4.5 \mathrm{~cm}$. On cut surfaces, a well demarcated solid, greyish-livid tumor measuring $3.5 \mathrm{~cm} \times 3 \mathrm{~cm} \times$ $3 \mathrm{~cm}$, with bulging surface, appeared. The surrounding splenic tissue was unremarkable (Figure 1).

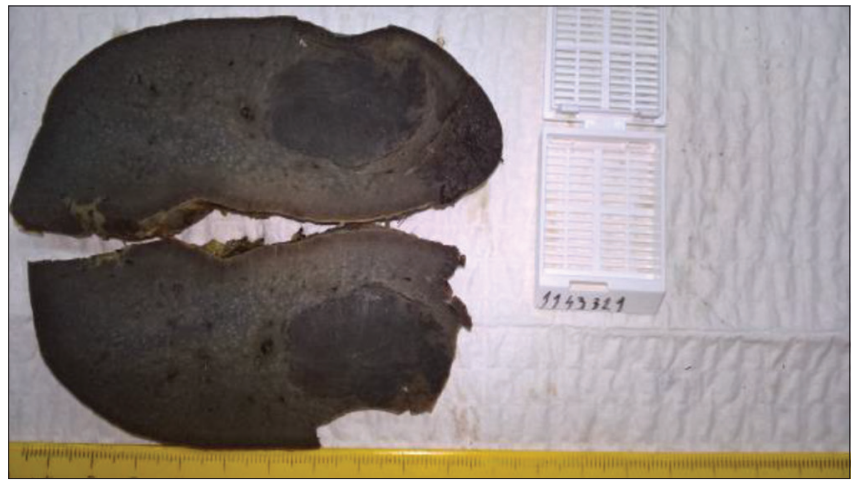

Figure 1: Cut surface of the spleen

\section{Microscopic findings}

The tumor mass was composed of loosely arranged, elongated oval and plump spindle cells admixed with pleomorphic inflammatory cells (histiocytes, lymphocytes, neutrophils, eosinophils, occasional plasma cells, and/or plasmacytoid cells) with varying density and multifocal clustering. There was multifocal deposition of fibrinoid-like material in the stroma in fascicular and net-like fashion. Throughout the lesion, there were dilated thin-walled and larger blood vessels with multifocal hemorrhage (Figure 2).
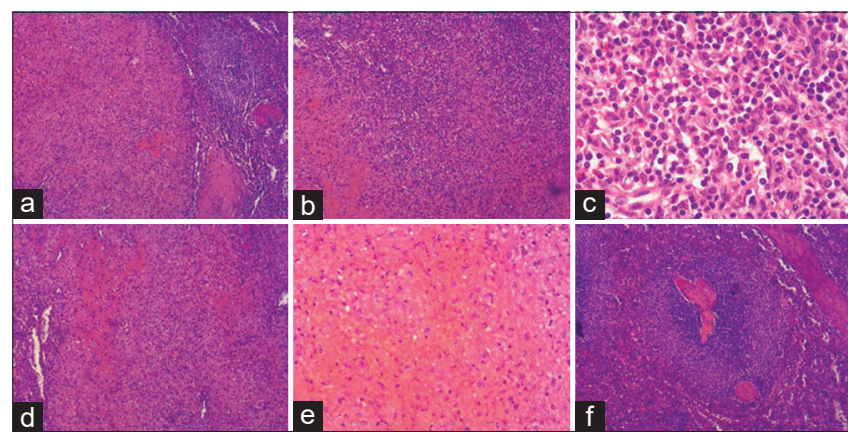

Figure 2: Microphotographs of the splenic lesion. $H$ and $E$ staining. (a) Well demarcated tumor border from the surrounding splenic tissue. (b) Variable cellularity within the lesion. (c) Loosely arranged spindle cells with admixed inflammatory cells including lymphocytes, histiosites, plasma cells, several eosinophils, and neutrophils. (d) Focal fibrinoid-like deposition, (e) focus of hemorrhage, (f) white pulp follicle with expanded marginal zone in otherwise unremarkable surrounding splenic tissue

Immunohistochemical stainings for CD3, CD20, CD68, CD138, kappa, and lambda immunoglobulin light chains, highlighted the cellular composition and distribution of the inflammatory cells within the lesion as well as in the surrounding splenic tissue. The smooth-muscle actin and S-100A4 revealed diffuse proliferation of myofibroblastic cells with variable density within the lesion. The proliferation index (Ki-67) was lower than 5\% (Figure 3).

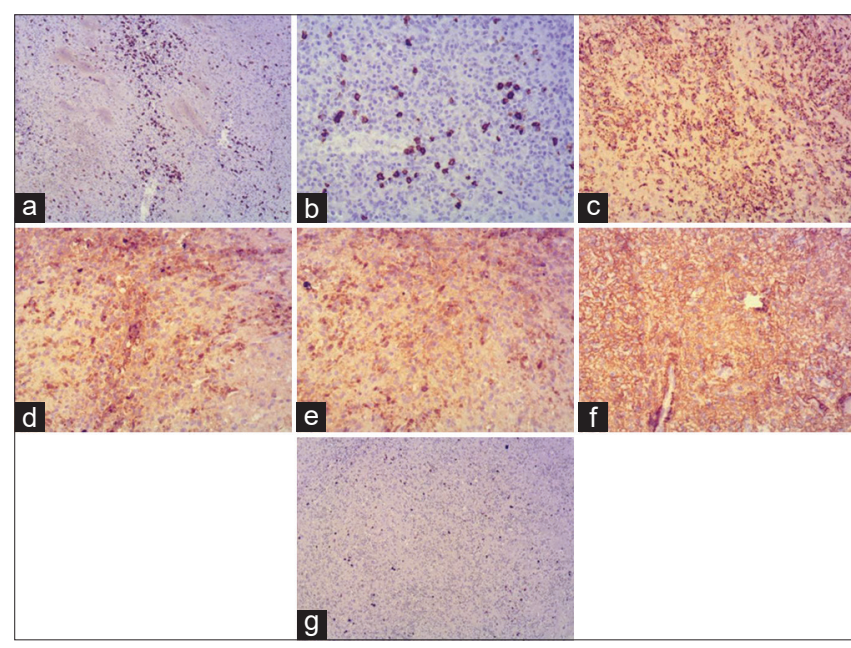

Figure 3: Microphotographs of immunohistochemical staining (EnVision flex $D A K O)$ depicting cellular composition, relative relations, and distribution. (a) $T$ lymphocyte clusters within the lesion (CD3 staining; $\times 40)$. (b) B-lymphocytes (CD20 staining; $\times 100)$ (c) number of histiocytes diffusely distributed (CD68 staining; $\times 40)$ ( $d$ and e) kappa and lambda light immunoglobulin chains showing polyclonal pattern of immunohistochemical expression (Kappa; Lambda stain; $\times 40$ ) (f) diffuse positivity for smooth muscle actin (stain; $\times 40$ ) (g) low proliferation index $(<5 \%)(K i-67$ staining; $\times 40)$ 
The crystal violet and Ziehl-Neelsen stains were negative, as well as EBV and ALK1 immunostains (not shown). Surrounding splenic tissue showed focal marginal zone expansion in some of the white pulp follicles and increased intrafollicular T-cell influx (Figure 4).

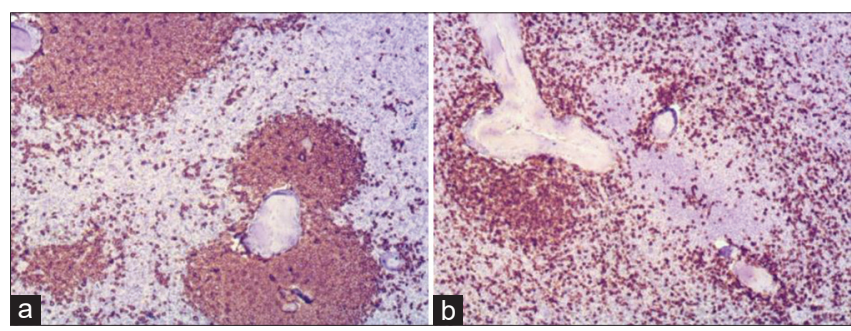

Figure 4: Microphotographs of immunohistochemical stainings (EnVision flex; DAKO) for $B$ and $T$ lymphocytes in the white pulp of the peritumoral splenic tissue. (a) B-lymphocytes in the reactive lymphoid follicle with expanded marginal zone (CD20 staining; $\times 40)$.

(b) Increased T-lymphocyte influx in some of the reactive lymphoid follicles (CD3 staining; $\times 40)$

Epstein-Barr encoded RNA test was not performed because of low RNA quality. Tumor DNA was subjected to next-generation sequencing using 15 genes panel covering: AKT1, BRAF, EGFR, ERBB2, FOXL2, GNA11, GNAQ, KIT, KRAS, MET, NRAS, PDGFRA, PIK3CA, RET, and TP53 (TruSight Tumor 15 panel on Miseq DX; Illumina). Next-generation sequencing (NGS) revealed homozygous TP53 polymorphism (c.215C>G; p.Pro72Arg), besides several intronic and synonymous variations with no clinical significance, as well as five low confidence missense single nucleotide variations (SNVs) (Table 1).

Table 1: Next-generation sequencing: TruSight tumor 15 missense single nucleotide variations (low confidence)

\begin{tabular}{|c|c|c|c|c|c|}
\hline Gene transcript & Exon & $\begin{array}{l}\text { c.DNA } \\
\text { prot. } \\
\text { alteration }\end{array}$ & $\begin{array}{l}\text { Variant fraction } \\
\text { coverage } \\
\text { (ref/alt) }\end{array}$ & Pathogenicity & ClinVar \\
\hline $\begin{array}{l}\text { AKT1 } \\
\text { NM_001014431 }\end{array}$ & 3 & $\begin{array}{l}\text { c.73C>T } \\
\text { p.(Arg25Cys) }\end{array}$ & $\begin{array}{l}1.19 \% \\
(13728 / 165)\end{array}$ & $\begin{array}{l}\text { Prediction: } \\
\text { Highly } \\
\text { pathogenic }\end{array}$ & $\begin{array}{l}\text { Pathogenic } \\
\text { rs397514644 }\end{array}$ \\
\hline $\begin{array}{l}\text { ERBB2 } \\
\text { NM_001005862 }\end{array}$ & 21 & $\begin{array}{l}\text { c. } 2024 \mathrm{C}>\mathrm{T} \\
\text { p.(Ala675Val) }\end{array}$ & $\begin{array}{l}1.26 \% \\
(4392 / 56)\end{array}$ & $\begin{array}{l}\text { Prediction: } \\
\text { Potentially } \\
\text { Pathogenic }\end{array}$ & \\
\hline $\begin{array}{l}\text { ERBB2 } \\
\text { NM_001005862 }\end{array}$ & 20 & $\begin{array}{l}\text { c. } 1957 \mathrm{C}>\mathrm{T} \\
\text { p.(Arg653Trp) }\end{array}$ & $\begin{array}{l}1.09 \% \\
(3815 / 42)\end{array}$ & $\begin{array}{l}\text { Prediction: } \\
\text { Potentially } \\
\text { pathogenic }\end{array}$ & \\
\hline $\begin{array}{l}\text { ERBB2 } \\
\text { NM_001005862 }\end{array}$ & 20 & $\begin{array}{l}\text { c. } 1972 \mathrm{C}>\mathrm{T} \\
\text { p.(Arg658Trp) }\end{array}$ & $\begin{array}{l}1.49 \% \\
(3758 / 57)\end{array}$ & $\begin{array}{l}\text { Prediction: } \\
\text { Potentially } \\
\text { pathogenic }\end{array}$ & \\
\hline $\begin{array}{l}\text { TP53 } \\
\text { NM_000546 }\end{array}$ & 8 & $\begin{array}{l}\text { c. } 917 G>A \\
\text { p.(Arg306GIn) }\end{array}$ & $\begin{array}{l}1.3 \% \\
(6458 / 85)\end{array}$ & $\begin{array}{l}\text { Prediction: } \\
\text { Potentially } \\
\text { pathogenic }\end{array}$ & \\
\hline
\end{tabular}

Our diagnosis was IPT/IMT of spleen. During the follow-up, 16 months after the operation the patient has had an uneventful recovery.

\section{Discussion}

Splenic IPT/IMT is a rare pseudotumor/ tumor of unknown origin, which is usually benign, although atypical and aggressive cases have been reported [2], [3], [4], [7], [8], [10], [11], [12], [13]. According to the available literature probably not more than 116 cases with splenic localization have been reported in adults, and more commonly in women. Clinically, it is often associated with fever of unknown origin and splenomegaly, may present with B symptoms including weight loss, fever, and abdominal pain, but may be an incidental finding as well [2]. The actual pathogenesis is unknown, although possible factors include bacterial infection, neoplastic processes, and immunological derangements with some cases being associated with EBV infection. Associations have been also reported with the previous surgery, ventriculoperitoneal shunt, trauma, radiation therapy, and steroid usage [2], [3], [4], [5], [6], [7]. None of these conditions have been identified in our patient during the diagnostic process, and none have additionally appeared 16 months after the surgery. Acknowledging that IPT and IMT lay in the spectrum of the same entity, the differential diagnosis includes splenic hamartoma, follicular dendritic cell tumor, and mycobacterial infection in immunocompromised patients [2], [3], [7]. Splenic hamartomas are tumor-like masses of disorganized but mature tissue indigenous to the spleen and is composed exclusively of red pulp elements, lacking follicles, or fibrous trabeculae [2], [3], [4]. Unlike IPT/ IMT, follicular dendritic cell tumor is smooth muscle actin negative, but CD21 and CD35 positive, ruling it out in our case [2], [3]. Mycobacterial infection in immunocompromised patients usually presents with nodules in the red pulp made up of CD68+ spindle cells which contain acid-fast bacilli in their cytoplasm. In our case, no acid-fast bacilli were identified, and the patient also did not present any other signs of immunodeficiency. In general, speaking, in cases where similar lesion is located outside the spleen or lymph nodes, a broader spectrum of differential diagnoses comes into play, including fibromatosis, nodular fasciitis, pseudoangiomatous stromal hyperplasia of the breast, myofibroblastoma, and phyllodes tumor with stromal overgrowth in breast, as well as entities like cranial fasciitis of childhood in cases where pediatric patients are involved [7], [9], [11], [13], [14], [15], [16], [17]. All of the previously mentioned entities are composed of proliferating spindle mesenchymal cells with varying site-specific clinical presentations and varying immunophenotypic features of the spindle fibroblastic/ myofibroblastic cells regarding the differential expression patterns of SMA, S-100, $\beta$-catenin, HER2, estrogen, and progesterone receptors [16], which helps distinguish them from each other and from IPT/IMT as well, besides the fact that most of them (in typical cases) lack the mixed inflammatory substrate characteristic for IPT/IMT.

However, in case IPT and IMT are accepted as separate entities, than excluding one of them would probably be additional challenge in each similar case. As far as distinction between IPT and IMT is concerned, according to the several authors including 
Gleason and Hornick and Kutok et al., and Coffin et al., IPT of lymph nodes and spleen is a non-neoplastic entity distinct from IMT, with most of the patients being adults [7], [10], [11]. On the other hand, unlike cases with nodal localization who frequently present systemic symptoms and laboratory abnormalities seen in a minority of IMT patients, splenic IPTs are often asymptomatic, and rarely associated with nodal lesions and vice versa, raising the possibility that even these two entities may be unrelated, despite histological similarity [7]. The analysis of the NGS data in our case revealed only the c.215C>G; p.Pro72Arg TP53 polymorphism as reliable finding, besides few more intronic and synonymous variations with no clinical significance. Low confidence SNVs detected in our patient (Table 1) were not considered as a reliable finding during the diagnostic process due to the low variant fraction coverage, but initiated an idea that if a reactive pseudotumors lesion was undergoing early steps of oncogenesis where certain fraction of cells was put under selective pressure for survival, it would be understandable that some of these cells would try to escape death by increasing survival signaling, thus possibly acquiring errors in some components of the affected signaling pathways, in our case AKT1, ERBB2, and TP53. Taking into consideration, the small fraction of cells that would normally escape the selective pressure by undergoing this initial oncogenic steps compared to the bulk of the cells in the lesion, suddenly the "low confidence" SNVs ( $<2 \%$ variant fraction) acquire new meaning, especially the highly pathogenic c.73C >T (p.Arg25Cys) SNV in the AKT1 gene. In the further development, these changes could provide selective advantage of this small fraction of cells leading to formation of a true neoplastic lesion featuring specific cell cycle derangements. In our opinion activation of tyrosine kinases [12] or other genetic variations that could be categorized as driver mutations, would favor true neoplasm (e.g. IMT) over reactive lesion like IPT, as defined originally. This could be a criterion for distinguishing cases of IPT versus IMT with the latter being a real tumor with specific genetic abnormalities. Although the incidence of IPT/ IMT is low, awareness of its existence is necessary, since its occurrence can sometimes lead to serious complications and may pose a diagnostic problem. The prognosis is favorable following splenectomy in most cases, although recurrences and even metastatic disease have been reported [7], [8], [10], [11], [12], [13]. Careful microscopic examination of the specimen is mandatory, due to possible misdiagnosis. We believe that extensive NGS analysis on archive samples would provide more data about the spectrum of possible genetic changes in these lesions, and subsequent correlation with the outcome may elucidate the issue of distinction between IPT and IMT. Such analyses would be further beneficial for establishing thresholds (regarding variant fraction coverage) for selecting significant NGS findings in lesions like IPM/IMT.

\section{Conclusion}

Although the incidence of IPT/IMT is low, awareness of its existence is necessary. The prognosis is favorable following splenectomy in most cases. Careful microscopic examination of the specimen is mandatory, due to possible misdiagnosis. We believe that extensive NGS analysis on archive samples would provide more data about the spectrum of possible genetic changes in lesions like IPM/IMT.

\section{References}

1. Cotelingam JD, Jaffe ES. Inflammatory pseudotumor of the spleen. Am J Surg Pathol. 1984;8(5):375-80. PMid:6329007

2. Neuhauser TS, Derringer GA, Thompson LD, FanburgSmith JC, Aguilera NS, Andriko J, et al. Splenic inflammatory myofibroblastic tumor (inflammatory pseudotumor): A clinicopathologic and immunophenotypic study of 12 cases. Arch Pathol Lab Med. 2001;125(3):379-85. PMid:11231487

3. Ma ZH, Tijan XF, Ma J, Zhao YF. Inflammatory pseudotumor of the spleen: A case report and review of published cases. Oncol Lett. 2013;5(6):1955-7. https://doi.org/10.3892/ol.2013.1286 PMid:23833674

4. McMahon G, Rady K, Prince MH. Inflammatory pseudotumor of the spleen. Hematol Rep. 2015;7(2):5905. https://doi. org/10.4081/hr.2015.5905

PMid:26331003

5. Ugalde P, Bernardo CG, Granero P, Miyar A, González C, González-Pinto I, et al. Inflammatory pseudotumor of spleen: A case report. Int J Surg Case Rep. 2015;7C:145-8.

PMid:25648471

6. Toumi O, Ammar H, Chhaidar A, Gupta R, Korbi I, Nasr M, et al. Inflammatory pseudotumor of spleen: A case report. Arch Clin Med Case Rep. 2017;1(1):31-4. https://doi.org/10.26502/ acmcr.9655006

7. Gleason CB, Hornick LJ. Inflammatory myofibroblastic tumours: Where are we now? J Clin Pathol. 2008;61(4):428-37. Doi:10.1136/jcp.2007.049387

PMid:17938159

8. Rajabi $\mathrm{P}$, Noorollahi $\mathrm{H}$, Hani $\mathrm{M}$, Bagheri $\mathrm{M}$. Inflammatory pseudotumor of spleen. Adv Biomed Res. 2014;3:29-38. https:// doi.org/10.4103/2277-9175.124679

PMid:24592376

9. Kim HJ, Cho HJ, Park SM, Chung HJ, Lee GJ, Kim SY, et al Pulmonary inflammatory pseudotumor. Korean J Intern Med. 2002;17(4):252-8.

PMid:12647641

10. Kutok JL, Pinkus GS, Dorfman DM, Fletcher CD. Inflammatory pseudotumor of lymph node and spleen: An entity biologically distinct from inflammatory myofibroblastic tumor. Hum Pathol. 2001;32(12):1382-7. https://doi.org/10.1053/hupa.2001.29679 PMid:11774173

11. Coffin CM, Hornick JL, Fletcher CD. Inflammatory myofibroblastic tumor: Comparison of clinicopathologic, histologic, and immunohistochemical features including 
ALK expression in atypical and aggressive cases. Am J Surg Pathol. 2007;31(4):509-20. https://doi.org/10.1097/01. pas.0000213393.57322.c7

PMid:17414097

12. Davies DK, Villalobos MV, Aisner LD. Ready or not here I come: Inflammatory myofibroblastic tumors with kinase alterations revealed through molecular hide and seek. J Thorac Oncol. 2019;14(5):758-60. https://doi.org/10.1016/j.jtho.2019.02.006 PMid:31027738

13. Salehinejad J, Pazouki M, Gerayeli MA. Malignant inflammatory myofibroblastic tumor of the maxillary sinus. J Oral Maxillofac Pathol. 2015;17(2):306-10. https://doi. org/10.4103/0973-029x.119754

PMid:24250100

14. Khanafshar E, Phillipson J, Schammel DP, Minobe L, Cymerman J, Weidner N. Inflammatory myofibroblastic tumor of the breast. Ann Diagn Pathol. 2005;9(3):123-9. https://doi. org/10.1016/j.anndiagpath.2005.02.001

PMid:15944952

15. Zardawi IM, Clark D, Williamsz G. Inflammatory myofibroblastic tumor of the breast. A case report. Acta Cytol. 2003;47(6):107781. https://doi.org/10.1159/000326651

PMid: 14674084

16. Krings $G$, McIntire P, Shin SJ. Myofibroblastic, fibroblastic and myoid lesions of the breast. Semin Diagn Pathol. 2017;34(5):42737. https://doi.org/10.1053/j.semdp.2017.05.010 PMid:28751104

17. Zavras N, Poddighe D. Cranial fasciitis of childhood (CFC): An unusual clinical case of a rare disease. BMJ Case Rep. 2017;2017:220859. https://doi.org/10.1136/ bcr-2017-220859

PMid:28903973 